Readers who found these articles interesting may also like to read these papers that can be found in recent issues of our sister publications, Seminars in Thoracic and Cardiovascular Surgery and Operative Techniques in Thoracic and Cardiovascular Surgery.

\title{
THORACIC
}

\section{Esophageal Cancer}
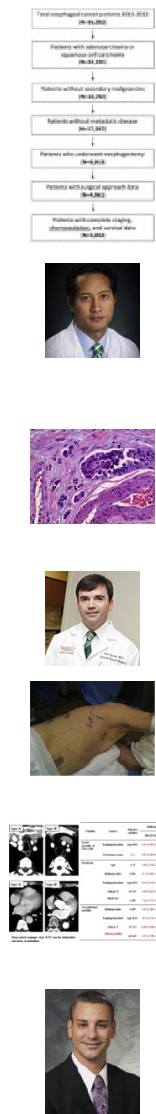

ORIGINAL SUBMISSION: Minimally Invasive Esophagectomy Provides Equivalent Survival to Open Esophagectomy: an Analysis of the National Cancer Data Base. Brian Mitzman. Semin Thoracic Surg 2017: 244-253.

Editorial Commentary: Is the Glass Half Full or Empty? Minimally Invasive Esophagectomy in an Age of Alternative Facts. Benjamin Wei. Semin Thoracic Surg 2017: 254-255.

ORIGINAL SUBMISSION: Node-Negative Esophageal Cancer With Short-Interval Isolated Metastasis to the Gallbladder: A Case Report. Christopher M. Hart. Semin Thoracic Surg 2017: 115-117.

Editorial Commentary: Signet Rings Around the World Philip Carrott. Semin Thoracic Surg 2017: 118.

CURRENT READINGS: The 5 Most Important Recent Publications Regarding Robotic Esophageal Surgery. Zane Hammoud. Semin Thoracic Surg 2016: 147-150.

ORIGINAL SUBMISSION: Effect of Esophagus Position on Surgical Difficulty and Postoperative Morbidities After Thoracoscopic Esophagectomy. Naoya Yoshida. Semin Thoracic Surg 2016: 172-179.

Editorial Commentary: Digging Deeper to Understand the Challenges of Minimally Invasive Esophagectomy. Ryan A. Macke. Semin Thoracic Surg 2016: 180-181.

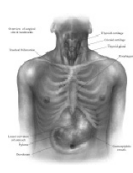

ORIGINAL SUBMISSION: Total

Laryngopharyngoesophagectomy and Tracheal Resection With Free Tissue-Reinforced Gastric PullUp. Michael Reilly. Oper Tech Thorac Cardiovasc 2016: 31-46.

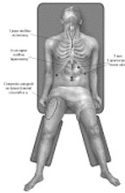

ORIGINAL SUBMISSION: Mediastinal Tracheostomy With Vessel Transposition and Minimally Invasive Transhiatal Esophagectomy. Christa N. Grant. Oper Tech Thorac Cardiovasc 2016: 47-64.

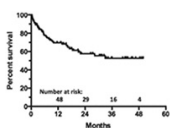

ORIGINAL SUBMISSION: Robotic Esophagectomy for Cancer: Early Results and Lessons Learned. Robert J. Cerfolio. Semin Thoracic Surg 2016: 160-169.

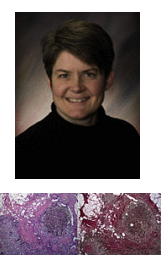

Editorial Commentary: Improving Quality: When Surgeons Take the Bit Between the Teeth, Patients Win! Katie S. Nason. Semin Thoracic Surg 2016: 170-171.

ORIGINAL SUBMISSION: Prognostic Relevance of Lymph Node Regression After Neoadjuvant Chemoradiation for Esophageal Cancer. Annouck Philippron. Semin Thoracic Surg 2016: 549-558.

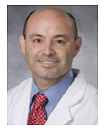

Editorial Commentary: Esophageal Cancer: Improvements in Treatment, Staging, and Now Prognostic Indicators? Mark F. Berry. Semin Thoracic Surg 2016: 559-560.
Esophagus
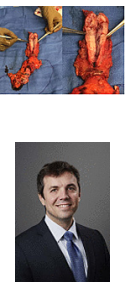

ORIGINAL SUBMISSION: Black and White Esophagus: Rare Presentations of Severe Esophageal Ischemia. Daniel B. Kim. Semin Thoracic Surg 2017: 256-259.

Editorial Commentary: Black Esophagus, White Esophagus, or Shades of Gray? Justin D. Blasberg. Semin Thoracic Surg 2017: 260-261.
STATE OF THE ART: The State of The Art in Per-Oral Endoscopic Myotomy. Stavros N. Stavropoulos. Semin Thoracic Surg 2016: 137-146. 


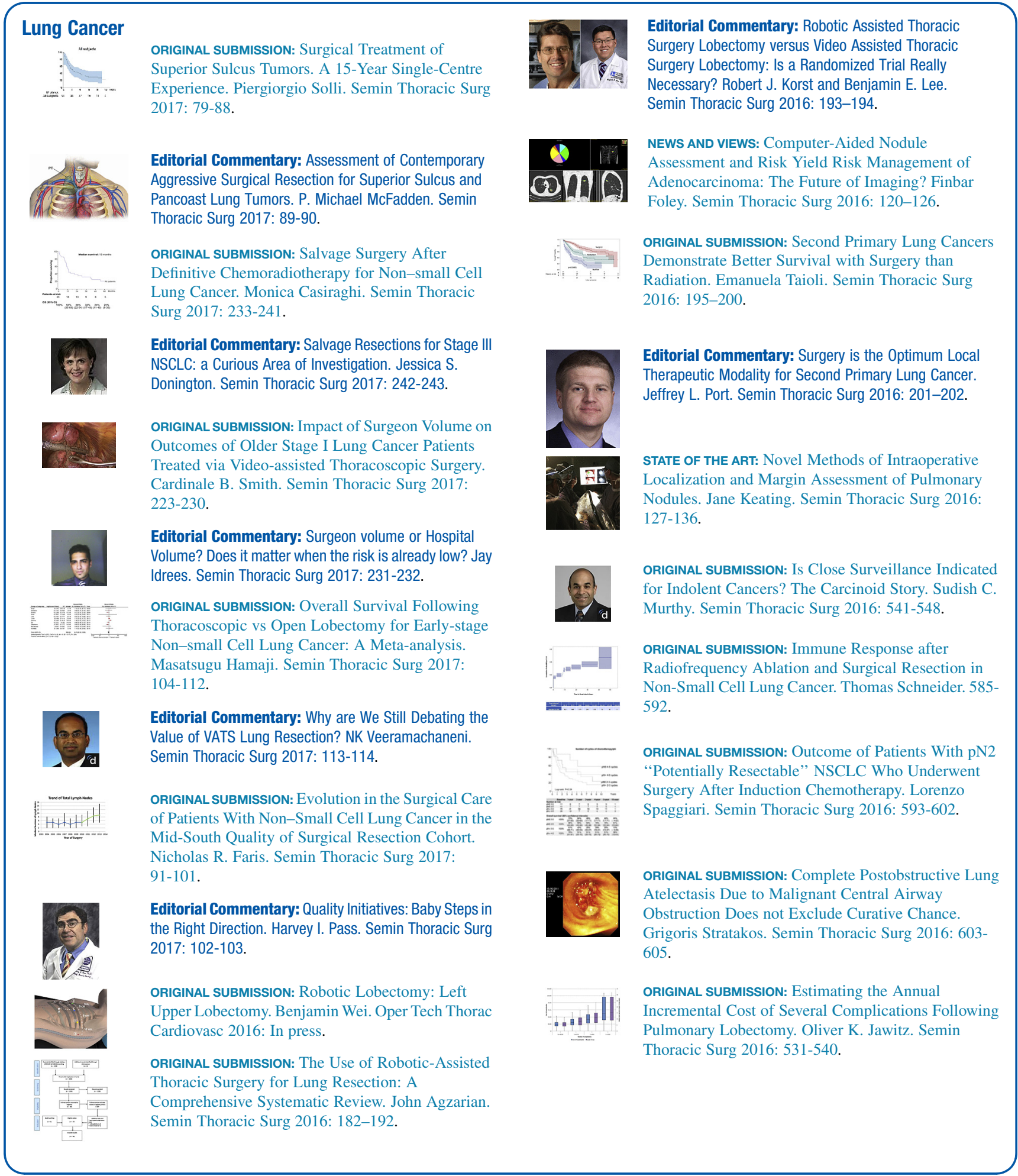




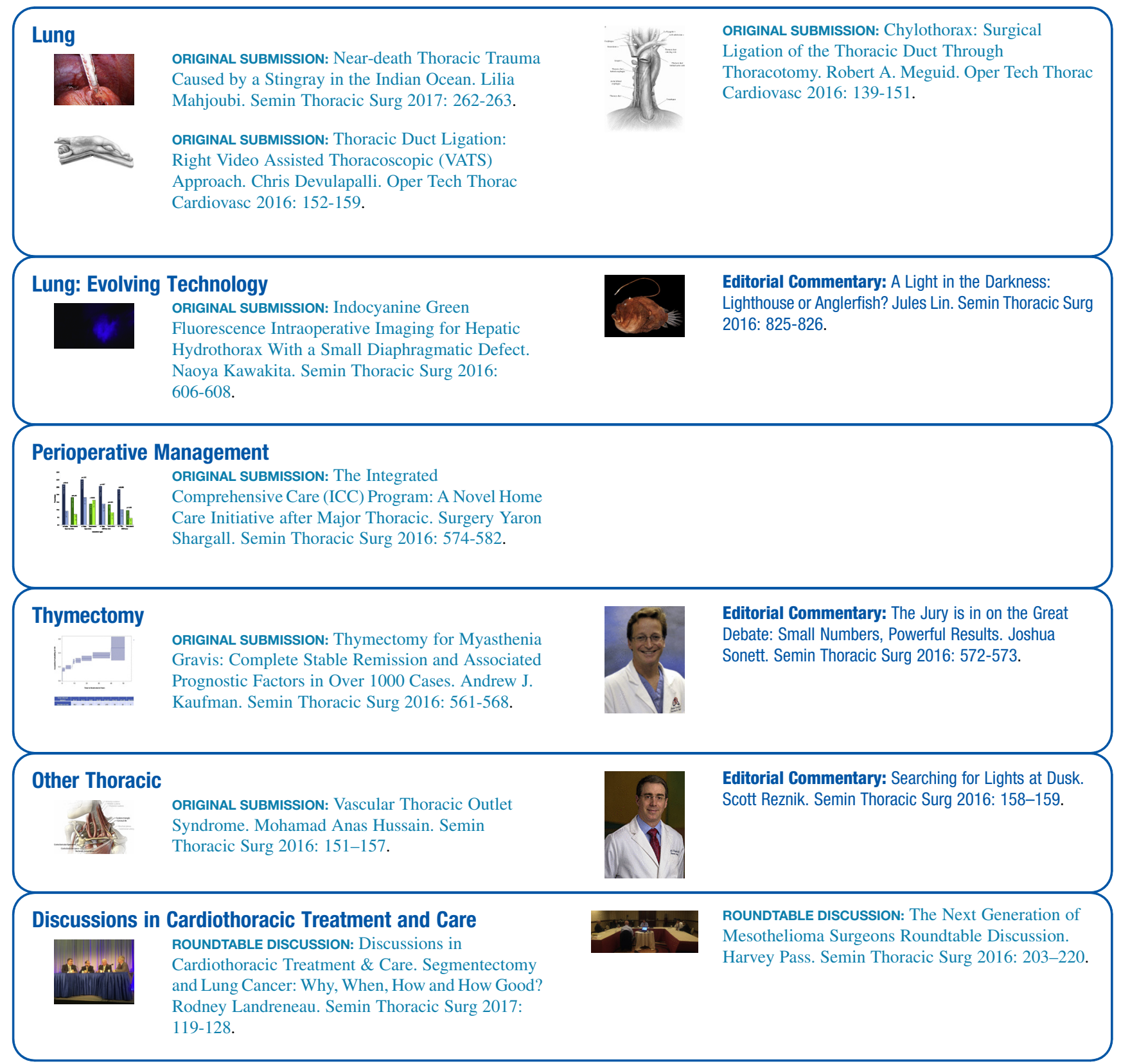

\section{ACQUIRED}

ORIGINAL SuBmissıon: Open Aortic Arch
Reconstruction After Coronary Artery Bypass
Surgery: Worth the Effort? Eduard Quintana. Semin
Thoracic Surg 2016: 26-35.




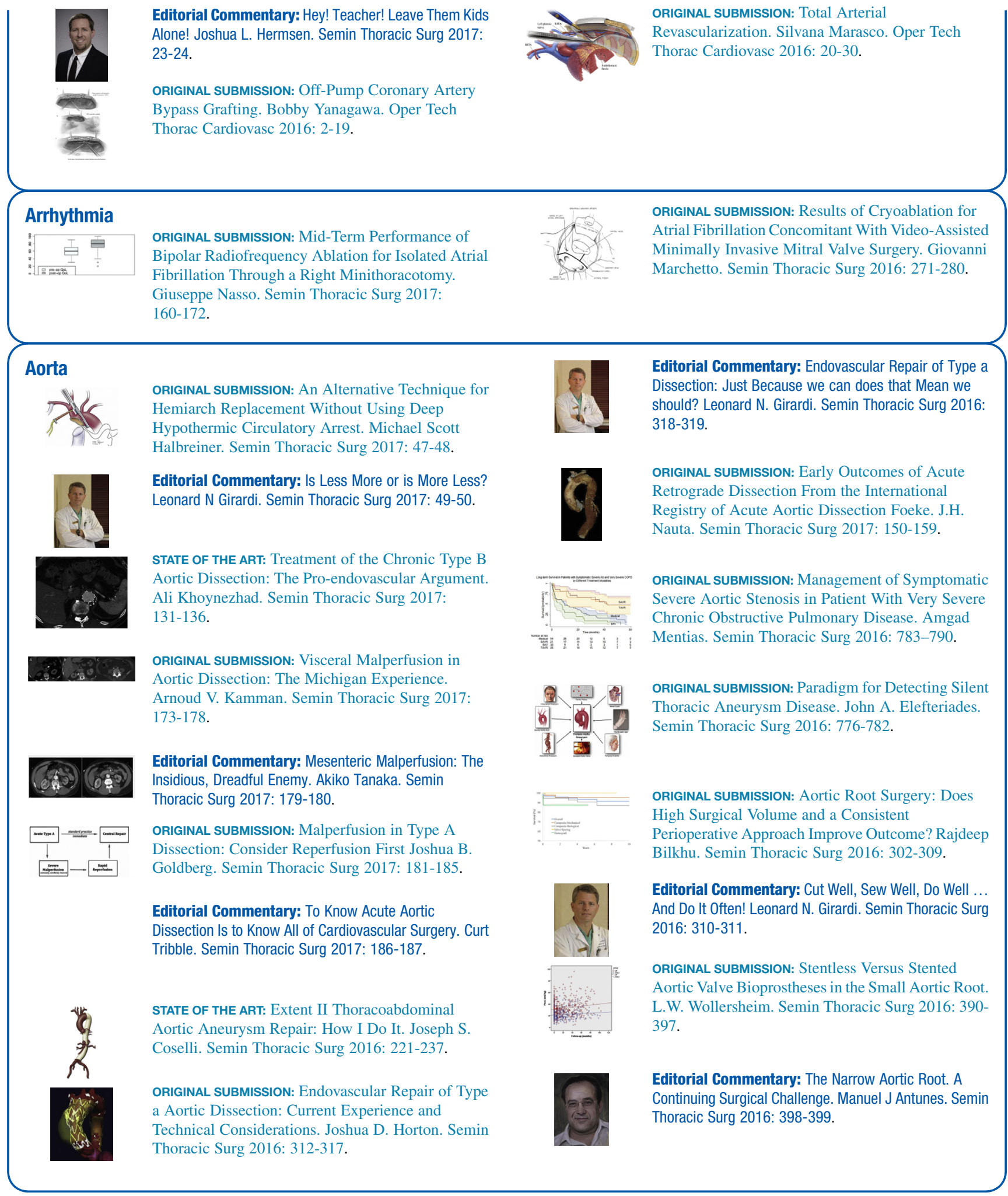




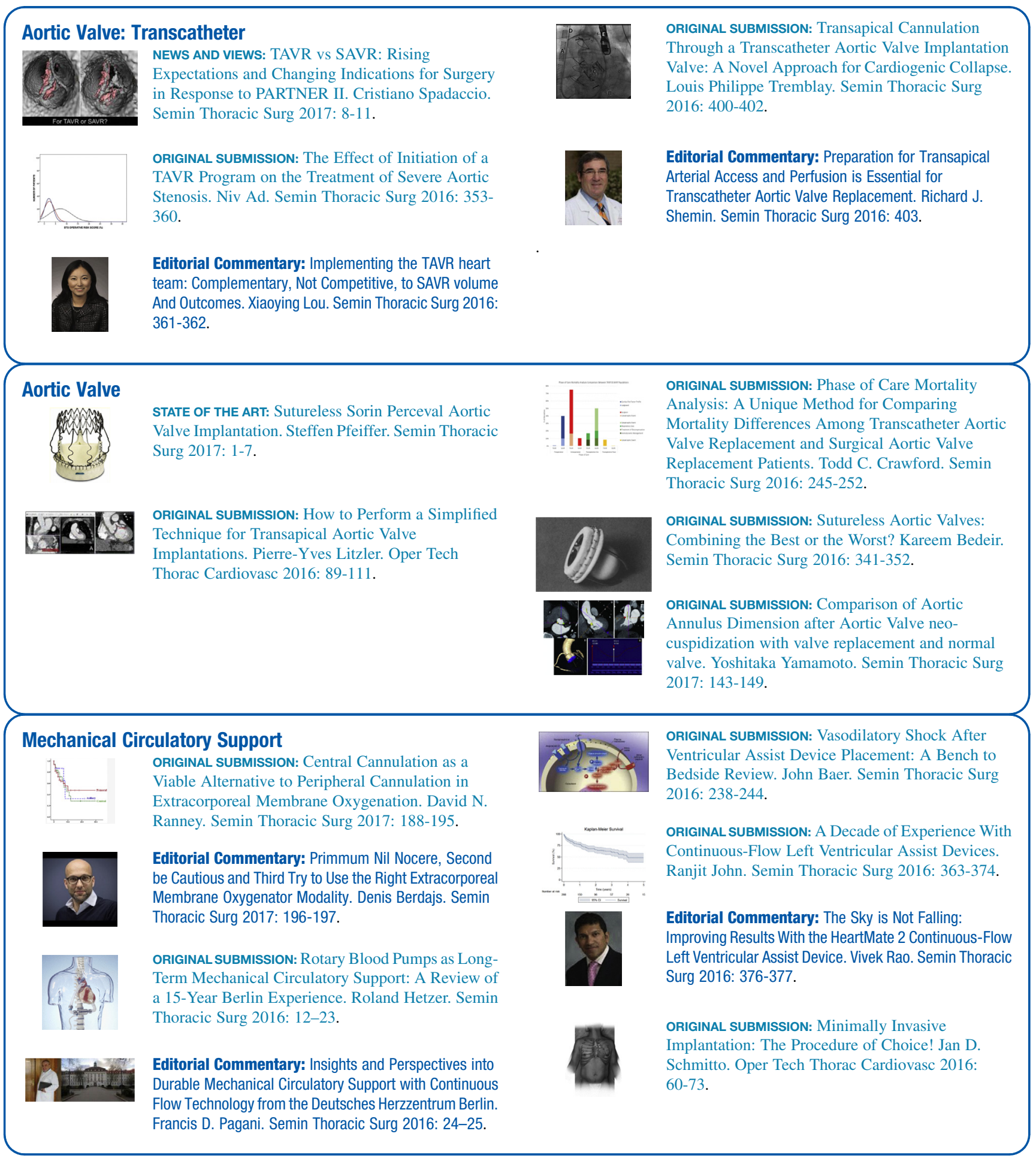




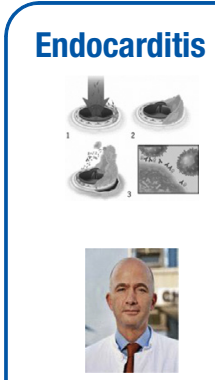

ORIGINAL SUBMISSION: Current Hypotheses in Cardiac Surgery: Biofilm in Infective Endocarditis. Haytham Elgharably. Semin Thoracic Surg 2016: $56-59$.

Editorial Commentary: Treatment of Infective Endocarditis-Are We On the Right Track? HansJoachim Schäfers. Semin Thoracic Surg 2016: 60-61.

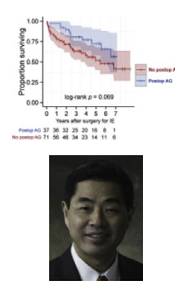

ORIGINAL SUBMISSION: Aminoglycosides For Surgically Treated Enterococcal Endocarditis. Jona M. Banzon. Semin Thoracic Surg 2016: 331-338.

Editorial Commentary: Aminoglycosides for Surgically Treated Enterococcal Endocarditis: A Contemporary Reassessment. David D. Yuh. Semin Thoracic Surg 2016: 339-340.

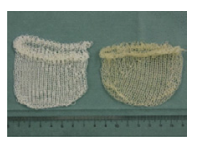

Evolving Technology

ORIGINAL SUBMISSION: Biodegradable vs

Nonbiodegradable Cardiac Support Device for

Treating Ischemic Cardiomyopathy in a Canine

Heart. Mutsunori Kitahara. Semin Thoracic Surg 2017: 51-61.

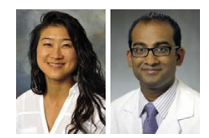

Editorial Commentary: New and Improved: Implications of a Cardiac Support Device Composed of Biodegradable Materials. Jennifer J. Chung and Pavan Atluri. Semin Thoracic Surg 2017: 62-63.

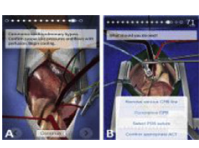

ORIGINAL SUBMISSION: Creation and Global Deployment of a Mobile, Application-Based Cognitive Simulator for Cardiac Surgical Procedures. Zachary E. Brewer. Semin Thoracic Surg 2016: 1-9.

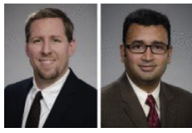

Editorial Commentary: "And"' is Better Than "Or." Joshua L. Hermsen and Nahush A. Mokadam. Semin Thoracic Surg 2016: 10-11.

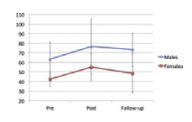

ORIGINAL SUBMISSION: Evaluation of a High-fidelity Simulation Training Program for New

Cardiothoracic ICU Nurses. Bryan Boling. Semin Thoracic Surg 2016: 770-775

\section{Basic Science}

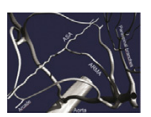

ORIGINAL SUBMISSION: Immediate Spinal Cord Collateral Blood Flow During Thoracic Aortic Procedures: The Role of Epidural Arcades. Fabian A. Kari. Semin Thoracic Surg 2016: 378-387.

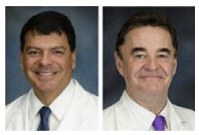

Editorial Commentary: Spinal Cord Collateral

Pathways-The Road Not Taken. Abe DeAnda Jr and Patrick T. Roughneen. Semin Thoracic Surg 2016: 388-389.

\footnotetext{
Mitral Valve
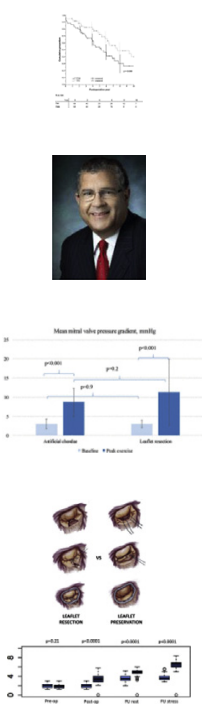

ORIGINAL SUBMISSION: Should Moderate-to-Severe Tricuspid Regurgitation be Repaired During Reoperative Left-Sided Valve Procedures? Igor Gosev. Semin Thoracic Surg 2016: 38-45.

Editorial Commentary: To Fix or Not to Fix? That is the Question. Kenton J. Zehr. Semin Thoracic Surg 2016: 46-47.

ORIGINAL SUBMISSION: Assessment of Mitral Valve Repair With Exercise Echocardiography: Artificial Chordae vs Leaflet Resection. Sigurdur Ragnarsson. Semin Thoracic Surg 2017: 25-32.

Editorial Commentary: The Dance of 2 Devils: Mitral Valve Repair and Functional Mitral Stenosis. Bobby Yanagawa. Semin Thoracic Surg 2017: 33-34.

ORIGINAL SUBMISSION: A Comparison of 2 Mitral Annuloplasty Rings for Severe Ischemic Mitral Regurgitation: Clinical and Echocardiographic Outcomes. Khalil Fattouch. Semin Thoracic Surg 2016: 261-268.
}

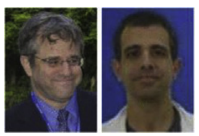

Editorial Commentary: Ischemic Mitral Regurgitation: The Value of Flexibility in the Quest for a Perfect Repair. Ronen Beeri and Amit Korach. Semin Thoracic Surg 2016: 269-270.

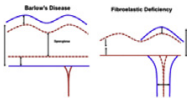

ORIGINAL SUBMISSION: Comparative

Histopathological Analysis of Mitral Valves in Barlow Disease and Fibroelastic Deficiency. Jesper Hjortnaes. Semin Thoracic Surg 2016: 757-767.

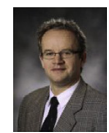

Editorial Commentary: Angel in the Architecture and the Devil in the Details: Comparative Ultrastructure of Degenerative Mitral Valve Disease. Tomasz A. Timek. Semin Thoracic Surg 2016: 768-769.

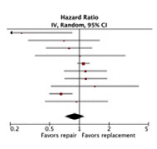

CURRENT READINGS: Similar Survival After Repair vs Replacement for Ischemic Mitral Regurgitation. Hisato Takagi. Semin Thoracic Surg 2016: 748-756. 


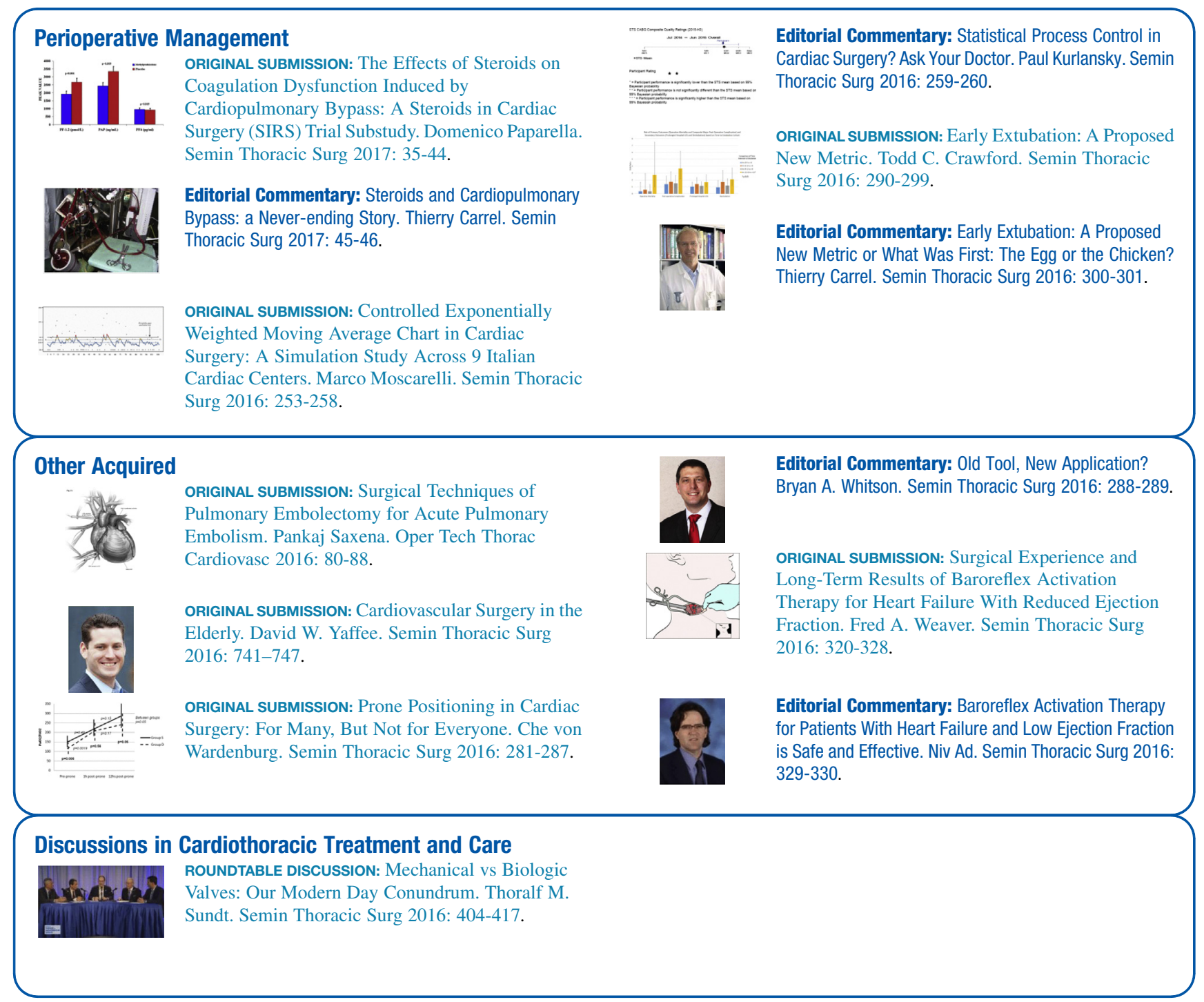

\section{CONGENITAL}

\section{Ebstein Anomaly}

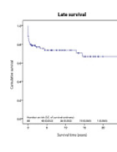

ORIGINAL SUBMISSION: Neonatal Ebstein Anomaly: A

30-year Institutional Review. Jack C. Luxford.

Semin Thoracic Surg 2017: 206-212.
Editorial Commentary: Management of neonata Ebstein Anomaly: To thine own self be true. David M Overman. Semin Thoracic Surg 2017: 213-214. 


\section{Trachea \\ ORIGINAL SUBMISSION: Advances in Surgical \\ Treatment of Congenital Airway Disease. William S. \\ Ragalie. Semin Thoracic Surg 2016: 62-68. \\ Anomalous Coronary Artery

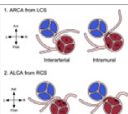 \\ ORIGINAL SUBMISSION: Anomalous Aortic Origin of \\ Coronary Arteries: A Single-Center Experience. \\ Assunta Fabozzo. Semin Thoracic Surg 2016: \\ 791-800.

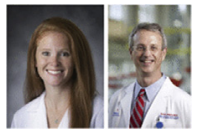 \\ Editorial Commentary: Wrong Sinus Coronary Arteries: Another Piece of the Puzzle. Kimberly W. Jackson and Robert D.B. Jaquiss. Semin Thoracic Surg 2016: 801-802. \\ Transposition

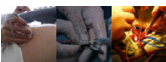 \\ ORIGINAL SUBMISSION: Five-year Experience With Arterial Switch Operation in the First Hours of Life. Kyrylo Chasovskyi. Semin Thoracic Surg 2017: 70-76.

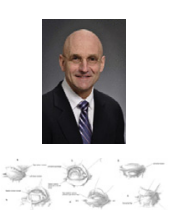 \\ Editorial Commentary: Blood Harvested? Cord Cut? Aortic Purse-string Please. Ronald K. Woods. Semin Thoracic Surg 2017: 77-78. \\ ORIGINALSUBMISSION: Single Center Experience with the Senning Procedure in the Current Era. Giuseppe Ferro. Semin Thoracic Surg 2016: 514-520.}

\section{Aortic Valve}

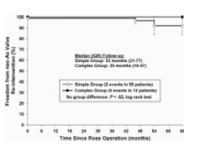

ORIGINAL SUBMISSION: Outcomes and Short-Term Follow-Up in Complex Ross Operations in Pediatric Patients Undergoing Damus-Kaye-Stansel Takedown. Christopher W. Baird. Semin Thoracic Surg 2016: 81-89.

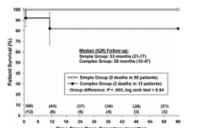

Editorial Commentary: Biventricular Repair With a Ross Procedure After a Norwood Procedure: A Big Operation for a Big Problem. Kirk R. Kanter. Semin Thoracic Surg 2016: 90-91.

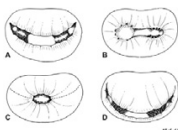

ORIGINAL SUBMISSION: Repair of Parachute and Hammock Valves in Infants and Children and its Long Term Outcome. Eva Maria Delmo Walter. Semin Thoracic Surg 2016: 448-460.

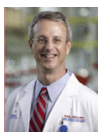

Editorial Commentary: Excellent Early; Not-SoExcellent Late. Robert D.B. Jaquiss. Semin Thoracic Surg 2016: 461-462.

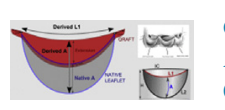

ORIGINAL SUBMISSION: Relationship of Normal Aortic Valve Cusp Dimensions: A Tool to Optimize Cusp Reconstruction Valvuloplasty. Sujata Subramanian. Semin Thoracic Surg 2016: 521-527.

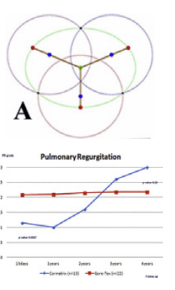

Editorial Commentary: Design of Replacement Leaflets for the Aortic Valve. J. Scott Rankin. Semin Thoracic Surg 2016: 528-530.

ORIGINAL SUBMISSION: Porcine Intestinal Submucosa (CorMatrix) for Semilunar Valve Repair in Children: A Word of Caution After Midterm Results. Massimo A. Padalino. Semin Thoracic Surg 2016: 436-445.

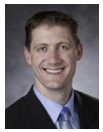

Editorial Commentary: Use of Cormatrix for Semilunar Valve Repair in Children: Variations on a Theme. Nicholas D. Andersen. Semin Thoracic Surg 2016: 446-447.

\section{Basic Science}

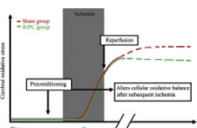

ORIGINAL SUBMISSION: Remote Ischemic

Preconditioning Reduces Cerebral Oxidative Stress Following Hypothermic Circulatory Arrest in a

Porcine Model. Oiva Arvola. Semin Thoracic Surg 2016: 92-102.

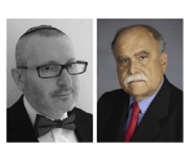

Editorial Commentary: Remote Ischemic

Preconditioning: A Quest for Reason. Edward Gologorsky. Semin Thoracic Surg 2016: 103-104.

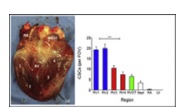

ORIGINAL SUBMISSION: Intracoronary Stem Cell Delivery To The Right Ventricle: A Preclinical Study. Brody Wehman. Semin Thoracic Surg 2016: 817-824.

\section{Cardiac Transplantation}

ORIGINAL SUBMISSION: Increasing Complexity of Heart Transplantation in Patients with Congenital Heart Disease. William Y. Shi. Semin Thoracic Surg 2016: 487-497.

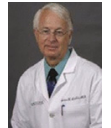

Editorial Commentary: Heart Transplantation for Complex Congenital Heart Disease: Will it Become an Arcane Activity? James K. Kirklin. Semin Thoracic Surg 2016: 498-499. 


\begin{tabular}{|c|c|c|}
\hline $\begin{array}{ll}\text { Hypoplastic Left Heart Syndrome } \\
\text { CuRRENT READINGS: Management of Tricuspid }\end{array}$ & 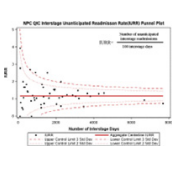 & $\begin{array}{l}\text { ORIGINAL SUBMISSION: Risk Factors for } \\
\text { Unanticipated Readmissions During the Interstage: } \\
\text { A Report From the National Pediatric Cardiology } \\
\text { Quality Improvement Collaborative. Samuel P. } \\
\text { Hanke. Semin Thoracic Surg 2016: 803-814. }\end{array}$ \\
\hline $\begin{array}{l}\text { ORIGINAL SUBMISSION: Staged Left Ventricular } \\
\text { Recruitment and Biventricular Conversion for Patients } \\
\text { with Borderline Left Heart. Sitaram M. Emani. Oper } \\
\text { Tech Thorac Cardiovasc 2016: 112-123. } \\
\text { ORIGINAL suBmIssion: Growing the Borderline } \\
\begin{array}{l}\text { Hypoplastic Left Ventricle: Hybrid Approach. } \\
\text { Christoph Haller. Oper Tech Thorac Cardiovasc } \\
\text { 2016: 124-138. }\end{array}\end{array}$ & & $\begin{array}{l}\text { Editorial Commentary: Unanticipated Readmissions } \\
\text { During the Interstage Period in Patients with Hypoplastic } \\
\text { Left Heart Syndrome: Can the Numbers be Safely } \\
\text { Reduced? Sarah Tabbutt. Semin Thoracic Surg 2016: } \\
\text { 815-816. }\end{array}$ \\
\hline $\begin{array}{l}\text { Perioperative Management } \\
\text { ORIGINAL SUBmissıon: The Effect of Noncardiac and } \\
\text { Genetic Abnormalities on Outcomes Following } \\
\text { Neonatal Congenital Heart Surgery. Bahaaldin } \\
\text { Alsoufi. Semin Thoracic Surg 2016: 105-117. }\end{array}$ & & $\begin{array}{l}\text { ORIGINAL SUBMISSION: Validation of a Simple Score } \\
\text { to Determine Risk of Hospital Mortality After the } \\
\text { Norwood Procedure Shahryar M. Chowdhury. } \\
\text { Semin Thoracic Surg 2016: 425-433. } \\
\text { Editorial Commentary: The Pearls and Perils of Settling } \\
\text { Scores in Public. Edward Buratto. Semin Thoracic Surg } \\
\text { 2016: 434-435. }\end{array}$ \\
\hline $\begin{array}{l}\text { Anomalous Pulmonary Vein } \\
\text { ORIGINAL SUBMISsion: Comparison of Sutureless and } \\
\text { Conventional Techniques to Repair Total } \\
\text { Anomalous Pulmonary Venous Connection. Cheng }\end{array}$ & & $\begin{array}{l}\text { Editorial Commentary: The Ongoing Evolution of } \\
\text { Sutureless Repairs for Pulmonary Vein Anomalies. Rachel } \\
\text { D. Vanderlaan and Christopher A. Caldarone. Semin } \\
\text { Thoracic Surg 2016: 485-486. }\end{array}$ \\
\hline $\begin{array}{l}\text { Tetralogy of Fallot } \\
\text { ORIGINAL SUBMIssion: Right Ventricular Outflow } \\
\text { Tract Reconstruction With a Polytetrafluoroethylene } \\
\text { Monocusp Valve: A 20-Year Experience. Mohineesh } \\
\text { Kumar. Semin Thoracic Surg 2016: 463-470. }\end{array}$ & & $\begin{array}{l}\text { Editorial Commentary: The Right Ventricular Outflow } \\
\text { Tract Reconstruction: A Challenge in Tetralogy of Fallot } \\
\text { Repair. Is There a Right Way of Doing It? An Art or a } \\
\text { Science? John M. Karamichalis. Semin Thoracic Surg } \\
\text { 2016: 471-472. }\end{array}$ \\
\hline $\begin{array}{l}\text { ORIGINAL SUBMISSION: Outcomes of truncus } \\
\text { arteriosus repair in children: } 35 \text { years of experience } \\
\text { from a single institution. Phillip S. Naimo. Semin }\end{array}$ & & $\begin{array}{l}\text { Editorial Commentary: The Initial Glimpse at Long- } \\
\text { Term Outcomes Following the Repair of Truncus } \\
\text { Arteriosus. George M. Alfieris. Semin Thoracic Surg } \\
\text { 2016: } 512-513 .\end{array}$ \\
\hline $\begin{array}{l}\text { Ventricular Septal Defect } \\
\text { ORIGINAL SUBMISSION: Long-Term Effect of } \\
\text { Enlargement of a Ventricular Septal Defect in the } \\
\text { Rastelli Procedure. Yasuyuki Toyoda. Semin } \\
\text { Thoracic Surg 2017: 215-220. }\end{array}$ & $\frac{1}{3}=1$ & $\begin{array}{l}\text { ORIGINAL SUBMISSION: Double-Outlet Right } \\
\text { Ventricle With Noncommitted Ventricular Septal } \\
\text { Defect and } 2 \text { Adequate Ventricles: Is Anatomical } \\
\text { Repair Advantageous? Olivier Villemain. Semin } \\
\text { Thoracic Surg 2016: 69-77. }\end{array}$ \\
\hline $\begin{array}{l}\text { Editorial Commentary: It's All in the Interpretation. Karl } \\
\text { F. Welke. Semin Thoracic Surg 2017: 221-222. }\end{array}$ & & $\begin{array}{l}\text { Editorial Commentary: Double Outlet Right Ventricle: } \\
\text { Where are we Now? Carl L. Backer. Semin Thoracic Surg } \\
\text { 2016: 79-80. }\end{array}$ \\
\hline
\end{tabular}

